\title{
Knowledge and Awareness About Esthetic Procedures in Periodontics Among Undergraduate Dental Students
}

\author{
Haripriya. $R^{1}$ and Arvina Rajasekar ${ }^{2}$ \\ ${ }^{1}$ Saveetha Dental College and Hospitals,Saveetha Institute of Medical \\ and Technical Sciences, Saveetha University,Chennai, India \\ ${ }^{2}$ Senior Lecturer, Department of Periodontics, Saveetha Dental College and Hospitals, \\ Saveetha Institute of Medical and Technical Sciences, Saveetha University,Chennai, India
}

\section{ABSTRACT}

The current level of awareness on beauty has driven a higher demand for aesthetic dentistry. The shape, position and appearance of the gingival tissue influences the aesthetics of the smile. Various techniques for gingival deformities have been introduced in recent years to meet the aesthetic needs of the patient with functional requirements. The aim of this study was to evaluate the knowledge and awareness about esthetic procedures in periodontics among undergraduate dental students. A 7-item questionnaire was prepared and circulated through an online portal among undergraduate dental students. A total of 100 students took up the survey among which 28 students were males and 72 students were females. The results obtained from the survey were tabulated, analysed and represented graphically using SPSS software (Version 23). Frequency distribution and percentage and chi-square test were done. In the present study, 86\% of the undergraduate students were aware of gummy smile, 72\% were aware of black triangle and $90 \%$ were aware of gingival hyperpigmentation. However, the knowledge on the treatment modalities for such conditions were inadequate. $48 \%$ were not aware of the treatment options for gummy smile, 42\% were not aware of various gingival depigmentation techniques. Also, females had more knowledge and awareness as compared to males. This study emphasizes the need for more awareness about the esthetic procedures in periodontics must be created among undergraduate dental students.

KEY WORDS: ESTHETICS; AWARENESS; GINGIVA; SURGICAL PROCEDURES.

\section{INTRODUCTION}

The current level of awareness on beauty has driven a higher demand for aesthetic dentistry. Aesthetic dental procedures and periodontal treatment have become inseparable. In the past, the aim of periodontal

\section{ARTICLE INFORMATION}

${ }^{*}$ Corresponding Author: mebingeorgem.sdc@saveetha.com Received 3rd Aug 2020 Accepted after revision 24th Sep 2020 Print ISSN: 0974-6455 Online ISSN: 2321-4007 CODEN: BBRCBA

Thomson Reuters ISI Web of Science Clarivate Analytics USA and Crossref Indexed Journal

\section{Clarivate
Analytics}

NAAS Journal Score 2020 (4.31) SJIF: 2020 (7.728)

A Society of Science and Nature Publication,

Bhopal India 2020. All rights reserved.

Online Contents Available at: http//www.bbrc.in/

Doi: http://dx.doi.org/10.21786/bbrc/13.8/197 treatment was directed more at preservation care and periodontal health restorations. However, the need to improve appearance in the recent years has increased the demand for aesthetic procedures in periodontics. (Jhamb, 2014) Assessment of gingival esthetics is of critical importance in patients with high lip line, where the gingival margins are clearly visible, as well as for patients with high esthetic demands.(Rufenacht, 2000) Treatment modalities for developing gingival harmony may involve periodontal surgeries.

Gingival recession presents as soft tissue pathology with various etiological factors and with a high prevalence in association with age.(Shkreta et al., 2018) Gingival recession is defined as an exposure of the root surface 
of the teeth as a result of apical migration of the gingival margin beyond the cementoenamel junction. (Gorman, 1967; Winders, 1971; Gartrell and Mathews, 1976) Periodontal surgery involves intrusion or extrusion techniques. Excess gingiva can be corrected by resection periodontal surgeries like gingivectomy or crown lengthening procedures Gingival recession can be corrected by additive periodontal surgical procedures like tissue grafts, guided tissue regeneration, etc. (Palmer, 1990; Tarnow, 1992; Prato, 2000; Periodontology, Research and Science and Therapy Committee of the American Academy of Periodontology, 2005)

There are various other aesthetic concerns like gingival hyperpigmentation, black triangle, etc. Open gingival embrasures are known as black triangles. It is a state of disappearance of the interdental papillae which serves as a biological barrier for the periodontal structures underneath. It also has an important role in aesthetics.
The gingival colour also contributes to a beautiful smile. (Grover et al., 2014) Excessive deposition of melanin on the supre basal layers of epithelium leads to gingival pigmentation. Various depigmentation techniques have been employed in the recent years. (Patil et al., 2015)

Previously we have worked on plenty of topics in periodontology (Ramesh, Ravi and Kaarthikeyan, 2017; Ravi et al., 2017; Arjunkumar, 2018; Gajendran, Parthasarathy and Tadepalli, 2018; Jain and Nazar, 2018; Kavarthapu and Thamaraiselvan, 2018; Ramesh et al., 2018, 2019; Ezhilarasan, Apoorva and Ashok Vardhan, 2019; Kaarthikeyan, Jayakumar and Sivakumar, 2019; Kavarthapu and Malaiappan, 2019; Murthykumar, Arjunkumar and Jayaseelan, 2019; Vijayashree Priyadharsini, 2019). Now we are planning to work on the knowledge and awareness on esthetic procedures in periodontics among undergraduate dental students.

Table 1. Questionnaire to assess the knowledge and awareness about esthetic procedures in periodontics.

\begin{tabular}{|c|c|c|}
\hline S.No & Questions & Options \\
\hline 1. & Are you aware of gummy smile? & $\begin{array}{l}\text { a. Yes } \\
\text { b. No }\end{array}$ \\
\hline 2. & What is the commonest treatment of choice for gummy smile? & $\begin{array}{l}\text { a. Gingivectomy } \\
\text { b. Flap Surgery }\end{array}$ \\
\hline 3. & $\begin{array}{l}\text { Are you aware that lip repositioning is done to } \\
\text { correct unesthetic gummy smile? }\end{array}$ & $\begin{array}{l}\text { a. Yes } \\
\text { b. No }\end{array}$ \\
\hline 4. & Are you aware of the term black triangle? & $\begin{array}{l}\text { a. Yes } \\
\text { b. No }\end{array}$ \\
\hline 5. & What do you think is the etiology of black triangle? & $\begin{array}{l}\text { a. Recession } \\
\text { b. Bone loss } \\
\text { c. Angulated root } \\
\text { d. All of the above } \\
\text { e. Not aware }\end{array}$ \\
\hline 6. & Are you aware of gingival depigmentation? & $\begin{array}{l}\text { a. Yes } \\
\text { b. No }\end{array}$ \\
\hline 7. & What are the gingival depigmentation methods you are aware of? & $\begin{array}{l}\text { a. Chemical method } \\
\text { b. Scalpel surgical technique } \\
\text { c. Gingival abrasion } \\
\text { d. All of the above } \\
\text { e. Not aware }\end{array}$ \\
\hline
\end{tabular}

\section{MATERIAL AND METHODS}

The present study was a questionnaire based study. A 7-item questionnaire was prepared (Table 1) and circulated through an online portal among undergraduate dental students. A total of 100 students took up the survey among which 28 students were males and 72 students were females. The results obtained from the survey were tabulated, analysed and represented graphically using SPSS software (Version 23). Frequency distribution and percentage was calculated. Then the chi-square test was done to find out the association between the responses with respect to gender.

\section{RESULTS AND DISCUSSION}

The present study was to evaluate the knowledge and awareness about esthetic procedures in periodontics among undergraduate dental students. A total of 100 undergraduate dental students took up the survey among which 28 were male students and 72 were female students. When the awareness of gummy smile was analysed, 21\% of the male respondents were aware of gummy smile and $65 \%$ of female respondents were aware of it. [Figure 1] When the common treatment option for gummy smile was analysed, 17\% of the male respondents responded as gingivectomy and 11\% responded as flap surgery. Among the female respondents, 52\% responded as 
gingivectomy, 20\% as flap surgery. [Figure 2] When the awareness on lip repositioning technique for unesthetic gummy smile was analysed, 19\% of the male respondents were aware of it while 9\% were not aware. $65 \%$ of the female respondents were aware and 7\% were not aware of it. [Figure 3]

Figure 1: Bar graph showing the association between gender and awareness of gummy smile. $\mathrm{X}$ axis represents the gender and $\mathrm{Y}$ axis represents the number of respondents who were aware and not aware of gummy smile. Majority of the female respondents (65\%) were aware of gummy smile. Association between gender and awareness of gummy smile was statistically significant. (Chi-square test; $p=0.048$ )

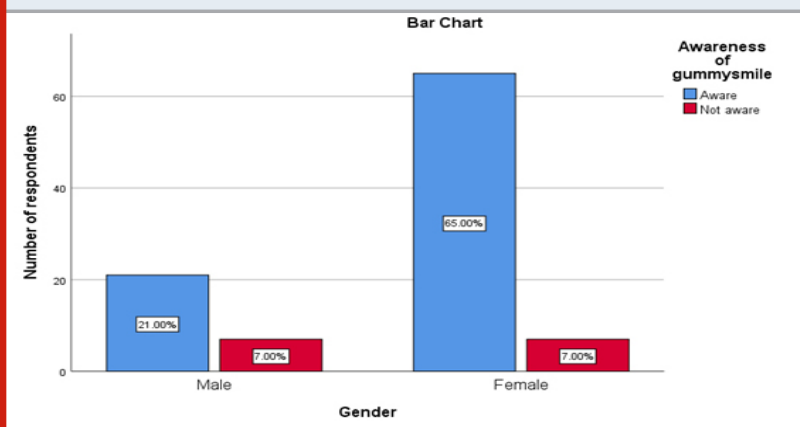

Figure 2: Bar graph showing the association between gender and awareness about the common treatment option for gummy smile. $\mathrm{X}$ axis represents the gender and $\mathrm{Y}$ axis represents the number of respondents who were aware and not aware of the common treatment option for gummy smile. Majority of the female respondents (52\%) were aware that gingivectomy is the common treatment option for gummy smile. However, association between gender and awareness about the common treatment option for gummy smile was not statistically significant. (Chisquare test; $p=0.264$ )

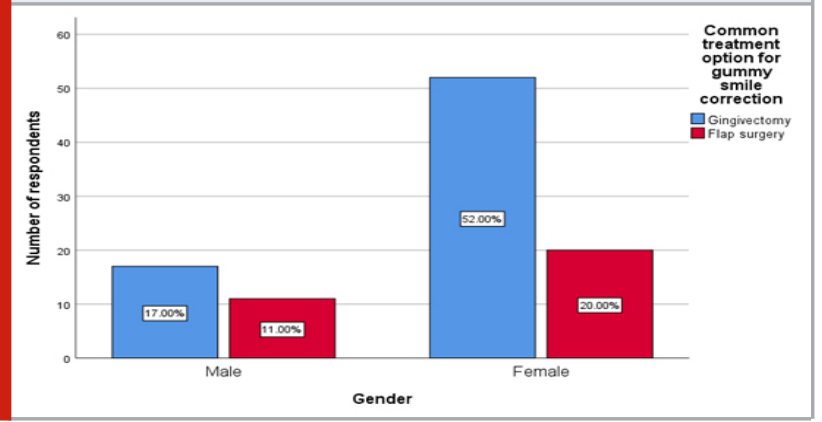

When the awareness of the term black triangle was analysed, 16\% of the male respondents were aware and $12 \%$ were not aware. Among the female participants, 57\% were aware of it while 15\% were not aware of it. [Figure 4] When the awareness on etiology of black triangle was analysed, $6 \%$ of male respondents were aware of all the causes while 11\% were not aware of it. Among the female respondents, 39\% were aware of all the causes while 15\% were not aware of the causes. [Figure 5] When the awareness on gingival depigmentation technique was analysed, 25\% of male respondents were aware of it while 3\% were not aware. Among female respondents, 65\% were aware of it and 7\% were not aware of it. [Figure 6] When the awareness on various gingival depigmentation methods were analysed, 5\% of male respondents were aware of all the techniques while 11\% were not aware of it. Among the female respondents, 17\% were aware of all the techniques while 31\% were not aware of it. [Figure 7].

Figure 3: Bar graph showing the association between gender and awareness about lip repositioning technique for unesthetic gummy smile. $\mathrm{X}$ axis represents the gender and $\mathrm{Y}$ axis represents the number of respondents who were aware and not aware of lip repositioning technique. Majority of the female respondents (65\%) were aware of the lip repositioning technique. Association between gender and awareness about lip repositioning technique for unesthetic gummy smile was statistically significant. (Chi-square test; $p=0.006$ ).

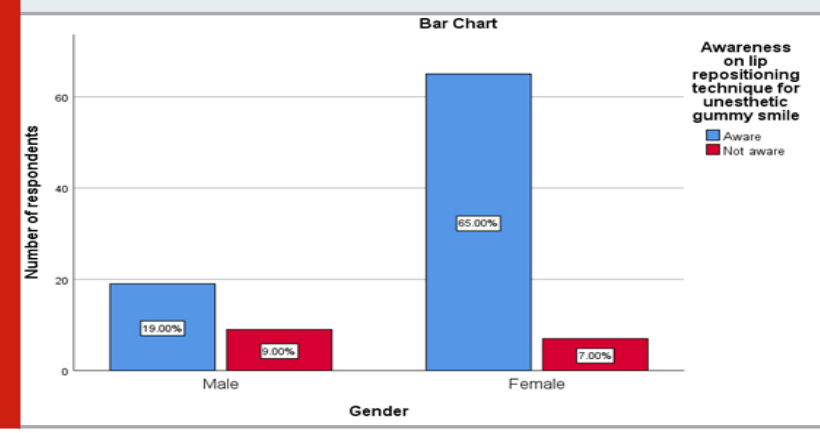

Figure 4: Bar graph showing the association between gender and awareness about the term black triangle. $\mathrm{X}$ axis represents the gender and $\mathrm{Y}$ axis represents the number of respondents who were aware and not aware of black triangle. Majority of the female respondents (57\%) were aware of the black triangle. Association between gender and awareness about the term black triangle was statistically significant. (Chi-square test; $\mathrm{p}=\mathbf{0 . 0 2 6}$ ).

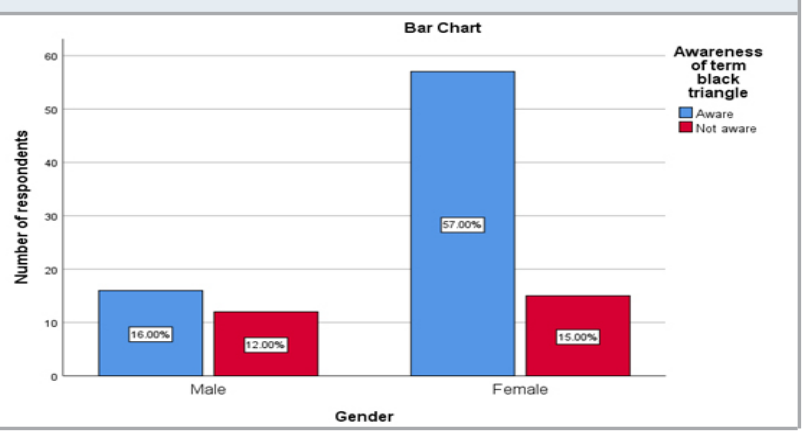

Cosmetic expectations have increased with time and patients are more concerned with gingival esthetics and smile designing in the recent years. Numerous procedures provide solutions to various esthetic deformities of the gingiva. The mucogingival defects include excessive gingiva, gingival recession, hyperpigmentation, etc. 
It can result in various conditions like black triangle, gummy smile, gingival hyperpigmentation, etc. Usually gingivoplasty, a resective gingival surgery is recommended. Recently techniques like lip repositioning, laser treatment have been introduced for correcting gummy smile.(Gonçalves et al., 2017)

Figure 5: Bar graph showing the association between gender and awareness about the etiology of black triangle. $\mathrm{X}$ axis represents the gender and $\mathrm{Y}$ axis represents the number of respondents who were aware and not aware of the etiology of black triangle. Majority of the female respondents (39\%) were aware of all the etiology of black triangle. Association between gender and awareness about the etiology of black triangle was statistically significant. (Chi-square test; $\mathrm{p}=0.004$ )

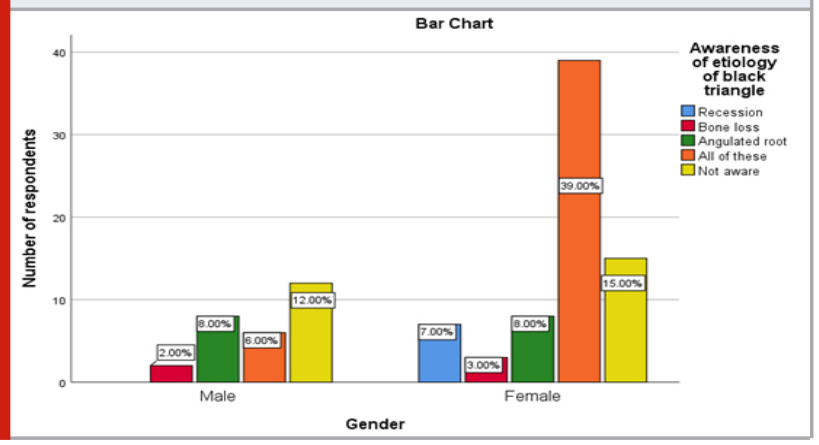

Figure 6: Bar graph showing the association between gender and awareness about gingival hyperpigmentation. $\mathrm{X}$ axis represents the gender and $\mathrm{Y}$ axis represents the number of respondents who were aware and not aware of the gingival depigmentation technique. Majority of the female respondents (65\%) were aware of gingival depigmentation technique. However, association between gender and awareness about gingival depigmentation technique was not statistically significant. (Chi-square test; $p=0.882$ )

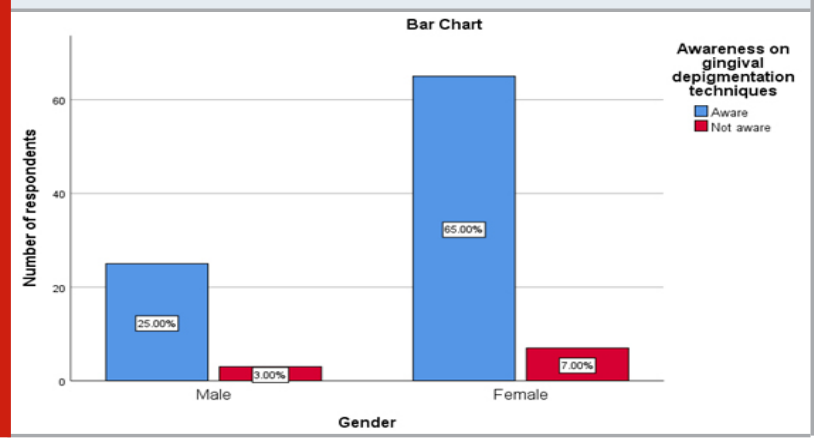

Loss of interdental papilla results in a condition called black triangle. One of the aesthetic difficulties in treatment of black triangle is related to its ability to restore the missing papilla in the maxillary anterior portion. (Lubis, Nasution and Zulkarnain, 2018) Various conditions like recession, bone loss, angulated root, triangular crown, aging, midline diastema have been reported to cause black triangle. (Al-Zarea et al., 2015) Various surgical and non surgical techniques are available to treat black
Figure 7: Bar graph showing the association between gender and awareness about gingival depigmentation techniques. $\mathrm{X}$ axis represents the gender and $\mathrm{Y}$ axis represents the number of respondents who were aware and not aware of the gingival depigmentation techniques. Only $17 \%$ of the female respondents were aware of all the gingival depigmentation techniques. Association between gender and awareness about gingival depigmentation techniques was not statistically significant. (Chi-square test; $\mathrm{p}=\mathbf{0 . 6 6 0}$ )

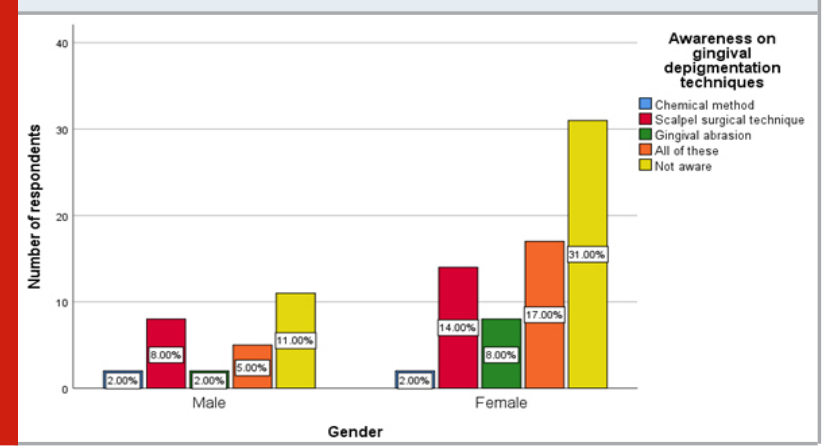

triangle, Surgical approach includes pedicle graft, envelope type flap, etc.(Ozenci, no date)

Gingival appearance is a component for an attractive smile. Gingival hyperpigmentation can occur due to deposition of melanin pigment. ('Surgical Gingival Depigmentation: A Case Report', 2012) Various depigmentation techniques have been introduced in the recent years. It includes surgical scalpel technique, bar abrasion method, electrosurgery, cryosurgery, laser , chemical exfoliation, etc. (S. et al., 2013; Hosadurga et al., 2017)

In the present study, $86 \%$ of the undergraduate students were aware of gummy smile, 72\% were aware of black triangle and 90\% were aware of gingival hyperpigmentation. However, the knowledge on the treatment modalities for such conditions were inadequate. $48 \%$ were not aware of the treatment options for gummy smile, $42 \%$ were not aware of various gingival depigmentation techniques.

\section{CONCLUSION}

From this study we can conclude that the majority of the students were aware of the gingival conditions like gummy smile, black triangle, gingival hyperpigmentation. However, many students were not aware of the various treatment modalities available for those conditions. Also, females had more knowledge and awareness as compared to males. This study emphasizes the need for more awareness about the esthetic procedures in periodontics must be created among undergraduate dental students.

\section{ACKNOWLEDGEMENTS}

The authors of this study would like to express their gratitude towards everyone who facilitated and enabled 
us to carry out this study successfully.

Conflict of Interest: None declared.

\section{REFERENCES}

Al-Zarea, K. et al. (2015) 'Black Triangles Causes and Management: A Review of Literature', British Journal of Applied Science \& Technology, pp. 1-7. doi: 10.9734/ bjast/2015/11287.

Arjunkumar, R. (2018) 'Nanomaterials for the Management of Periodontal Diseases', in Chaughule, R. S. (ed.) Dental Applications of Nanotechnology. Cham: Springer International Publishing, pp. 203-215.

Ezhilarasan, D., Apoorva, V. S. and Ashok Vardhan, N. (2019) 'Syzygium cumini extract induced reactive oxygen species-mediated apoptosis in human oral squamous carcinoma cells', Journal of oral pathology et medicine: official publication of the International Association of Oral Pathologists and the American Academy of Oral Pathology, 48(2), pp. 115-121.

Gajendran, P. L., Parthasarathy, H. and Tadepalli, A. (2018) 'Comparative evaluation of cathepsin K levels in gingival crevicular fluid among smoking and nonsmoking patients with chronic periodontitis', Indian journal of dental research: official publication of Indian Society for Dental Research, 29(5), pp. 588-593.

Gartrell, J. R. and Mathews, D. P. (1976) 'Gingival recession. The condition, process, and treatment', Dental clinics of North America, 20(1), pp. 199-213.

Gonçalves, K. J. et al. (2017) 'Periodontal plastic surgery for treatment of gummy smile with cosmetic restauration treatment', RSBO, p. 50. doi: 10.21726/rsbo. v1i1.386.

Gorman, W. J. (1967) 'Prevalence and etiology of gingival recession', Journal of periodontology, 38(4), pp. 316-322.

Grover, H. S. et al. (2014) 'Evaluation of patient response and recurrence of pigmentation following gingival depigmentation using laser and scalpel technique: A clinical study', Journal of Indian Society of Periodontology, 18(5), pp. 586-592.

Hosadurga, R. et al. (2017) 'Oral repigmentation after depigmentation - A short review and case report', Pigment International, p. 112. doi: 10.4103/23495847.219674.

Jain, M. and Nazar, N. (2018) 'Comparative Evaluation of the Efficacy of Intraligamentary and Supraperiosteal Injections in the Extraction of Maxillary Teeth: A Randomized Controlled Clinical Trial', The journal of contemporary dental practice, 19(9), pp. 1117-1121.

Jhamb, K. (2014) 'Clinical Evaluation of Papilla Reconstruction Using Subepithelial Connective Tissue Graft', JOURNAL OF CLINICAL AND DIAGNOSTIC
RESEARCH. doi: 10.7860/jcdr/2014/9458.4881.

Kaarthikeyan, G., Jayakumar, N. D. and Sivakumar, D. (2019) 'Comparative Evaluation of Bone Formation between PRF and Blood Clot Alone as the Sole SinusFilling Material in Maxillary Sinus Augmentation with the Implant as a Tent Pole: A Randomized Split-Mouth Study', Journal of long-term effects of medical implants, 29(2), pp. 105-111.

Kavarthapu, A. and Malaiappan, S. (2019) 'Comparative evaluation of demineralized bone matrix and type II collagen membrane versus eggshell powder as a graft material and membrane in rat model', Indian journal of dental research: official publication of Indian Society for Dental Research, 30(6), pp. 877-880.

Kavarthapu, A. and Thamaraiselvan, M. (2018) 'Assessing the variation in course and position of inferior alveolar nerve among south Indian population: A cone beam computed tomographic study', Indian journal of dental research: official publication of Indian Society for Dental Research, 29(4), pp. 405-409.

Lubis, P. M., Nasution, R. 0. and Zulkarnain (2018) 'Black Triangle, Etiology and Treatment Approaches: Literature Review', Proceedings of the International Dental Conference of Sumatera Utara 2017 (IDCSU 2017). doi: 10.2991/idcsu-17.2018.60.

Murthykumar, K., Arjunkumar, R. and Jayaseelan, V. P. (2019) 'Association of vitamin D receptor gene polymorphism (rs 10735810) and chronic periodontitis', Journal of investigative and clinical dentistry, 10(4), p. e12440.

Ozenci, I. (no date) 'Surgical and Restorative Management of Localized Gingival Recession Associated With Iatrogenic Factor: A Case Report'. doi: 10.26226/ morressier.5ac383252afeeb00097a464b.

Palmer, R. M. (1990) 'Free gingival graft for improvement of aesthetics', Restorative dentistry, 6(2), pp. 8-10.

Patil, K. P. et al. (2015) 'Gingival depigmentation: A split mouth comparative study between scalpel and cryosurgery', Contemporary clinical dentistry, 6(Suppl 1), pp. S97-S101.

Periodontology, R. S. A. T. C. of T. A. A. of, Research and Science and Therapy Committee of the American Academy of Periodontology (2005) 'Informational Paper: Oral Reconstructive and Corrective Considerations in Periodontal Therapy', Journal of Periodontology, pp. 1588-1600. doi: 10.1902/jop.2005.76.9.1588.

Prato, G. P. (2000) 'Advances in mucogingival surgery', Journal of the International Academy of Periodontology, 2(1), pp. 24-27.

Ramesh, A. et al. (2018) 'Comparative estimation of sulfiredoxin levels between chronic periodontitis and healthy patients - A case-control study', Journal of periodontology, 89(10), pp. 1241-1248. 
Ramesh, A. et al. (2019) 'Esthetic lip repositioning: A cosmetic approach for correction of gummy smile - A case series', Journal of Indian Society of Periodontology, 23(3), pp. 290-294.

Ramesh, A., Ravi, S. and Kaarthikeyan, G. (2017) 'Comprehensive rehabilitation using dental implants in generalized aggressive periodontitis', Journal of Indian Society of Periodontology, 21(2), pp. 160-163.

Ravi, S. et al. (2017) 'Additive Effect of Plasma Rich in Growth Factors With Guided Tissue Regeneration in Treatment of Intrabony Defects in Patients With Chronic Periodontitis: A Split-Mouth Randomized Controlled Clinical Trial', Journal of periodontology, 88(9), pp. 839-845.

Rufenacht, C. R. (2000) Principles of Esthetic Integration. Quintessence Publishing (IL).

Shkreta, M. et al. (2018) 'Exploring the Gingival Recession Surgical Treatment Modalities: A Literature Review', Open access Macedonian journal of medical sciences, 6(4), pp. 698-708.

S., S. K. et al. (2013) 'Gingival depigmentation: case series for four different techniques', Journal of Health and Allied Sciences NU, pp. 132-136. doi: 10.1055/s0040-1703720.

Surgical Gingival Depigmentation: A Case Report' (2012) The Internet Journal of Aesthetic and Antiaging Medicine. doi: 10.5580/2bfo.

Tarnow, D. P. (1992) 'Surgical considerations for the prosthodontic patient', Current opinion in dentistry, 2, pp. 34-38.

Vijayashree Priyadharsini, J. (2019) 'In silico validation of the non-antibiotic drugs acetaminophen and ibuprofen as antibacterial agents against red complex pathogens', Journal of periodontology, 90(12), pp. 1441-1448.

Winders, R. V. (1971) 'Gingival recession of mandibular incisors related to malocclusions of the teeth', The Journal of the Wisconsin State Dental Society, 47(11), pp. 339-343. 